\title{
Japanese knotweed and economic loss in nuisance: framing environmental harm in tort
}

Article

Accepted Version

Wilde, M. (2019) Japanese knotweed and economic loss in nuisance: framing environmental harm in tort. Journal of Environmental Law, 31 (2). pp. 343-349. ISSN 0952-8873 doi: https://doi.org/10.1093/jel/eqz016 Available at https://centaur.reading.ac.uk/83983/

It is advisable to refer to the publisher's version if you intend to cite from the work. See Guidance on citing.

To link to this article DOI: http://dx.doi.org/10.1093/jel/eqz016

Publisher: Oxford University Press

All outputs in CentAUR are protected by Intellectual Property Rights law, including copyright law. Copyright and IPR is retained by the creators or other copyright holders. Terms and conditions for use of this material are defined in the End User Agreement.

www.reading.ac.uk/centaur

\section{CentAUR}


Central Archive at the University of Reading

Reading's research outputs online 


\section{JAPANESE KNOTWEED AND ECONOMIC LOSS IN NUISANCE:}

\section{FRAMING ENVIRONMENTAL HARM IN TORT}

Dr Mark Wilde*

\section{Abstract}

In two recent cases, the courts have had to grapple with liability issues arising from the spread of Japanese Knotweed, a pernicious weed which is said to cause structural damage. One of those cases, Network Rail Infrastructure Ltd v Williams, was heard by the UK Court of Appeal where the arguments focused on the applicability of the tort of nuisance. The claimants were principally concerned about the property blight caused by the spread of the weed from a railway embankment onto their land. The litigation raises some important doctrinal points on the recoverability of economic loss in private nuisance. On a wider level, it also sheds light on how environmental harms can be framed as private financial losses which engage remedies in tort.

Keywords: tort, nuisance, invasive species, economic loss

\section{Introduction}

The subject of 'invasive species' and liability for the spread of such natural phenomena has received scant attention in UK case law. However, the subject has recently come to the fore In Network Rail Infrastructure Ltd $v$ Williams in the law of tort. ${ }^{1}$ The Court of Appeal, in an approved judgment delivered by Etherton MR, upheld a decision of the Cardiff County Court finding that Network Rail Infrastructure Ltd is liable in private nuisance for harm caused by the spread of Japanese Knotweed from its property; notwithstanding the fact that the harm fell short of actual structural damage to

\footnotetext{
${ }^{*}$ Associate Professor, School of Law, University of Reading, United Kingdom (m.l.wilde@reading.ac.uk).

${ }^{1}$ [2018] EWCA Civ 1514, [2018] 3 WLR 1105.
} 
neighbouring property. Although, as will be seen, the Court of Appeal disagreed with much of the reasoning applied by the County Court.

Aside from the liability implications for Network Rail, and other large landowners who may be in a similar position, the case raises a number of important doctrinal issues regarding the nature of harm in private nuisance and, in particular, how blight is conceptualized as actionable harm. Is it 'pure economic loss' and, if so, is this recoverable in private nuisance? In a specifically environmental context, these issues tie in with debates regarding how one frames certain environmental harms in a manner which engages liability in tort.

\section{Factual background to the case}

Japanese Knotweed (Fallopia Japonica) is a pernicious weed which was first introduced to the UK as an ornamental plant in the mid-nineteenth century. ${ }^{2}$ It is regarded as an invasive species, or 'nonnative' species to use the formal terminology, notwithstanding the length of time that it has been in the country. ${ }^{3}$ It spreads horizontally underground in an insidious manner and shoots up rhizomes which are capable of breaking through concrete and undermining foundations - although recent research suggests that the threat has been overstated. ${ }^{4}$ Railway embankments harbour all manner

\footnotetext{
2 JP Bailey and AP Conolly, 'Prize-Winners to Pariahs - a History of Japanese Knotweed s.I. (Polygonaceae) in the British Isles' (2000) 23 Watsonia 93.

${ }^{3}$ See Non-Native Species Secretariat (NNSS), 'Japanese Knotweed and Development' http://www.nonnativespecies.org/index.cfm?pageid=160 accessed 9 May 2019.

${ }^{4}$ See research undertaken by the University of Leeds and AECOM: Mark Fennell, Max Wade and Karen Bacon, 'Japanese Knotweed (Fallopia Japonica): an Analysis of Capacity to Cause Structural Damage (Compared to Other Plants) and Typical Rhizome Extension' (2018) PeerJ 6:e5246 https://doi.org/10.7717/peeri.5246 accessed 9 May 2019.
} 
of domestic and ornamental plants which have escaped the bounds of neighbouring gardens and this is how Japanese Knotweed entered the outside world.

The claimants in this case owned neighbouring bungalows in close proximity to a railway embankment on the Bridgend to Maesteg line in South Wales. It was estimated that the plant first took hold on the railway embankment about 50 years ago, but had been contained until more recent times. The essence of the claim was that rhizomes had infiltrated the foundations of the claimants' bungalows although they had yet to cause structural damage. Nevertheless, the properties were fatally blighted and had been rendered unsaleable with obvious financial implications.

\section{The County Court proceedings}

The Recorder, Judge Grubb, sitting in the Cardiff County Court, held in favour of the claimants on the grounds that, irrespective of any damage to the fabric of the property itself, the mere presence of an undesirable element in close proximity to the claimants' property constituted actionable harm. Although Network Rail was not responsible for bringing the weed onto its land in the first place, it was well established that one can be liable for continuing a nuisance that one did not originally cause. This is provided that one has control over the nuisance and failed to take steps to abate it which introduces an element of fault into the equation. ${ }^{5}$ Network Rail was found to be at fault in that it had constructive knowledge of the problem, but failed to take adequate steps to abate it. ${ }^{6}$

\footnotetext{
${ }^{5}$ See, for example, Sedleigh-Denfield v O'Callaghan [1940] AC 880 and Leakey $v$ National Trust for Places of Historic Interest or Natural Beauty [1980] QB 485.

${ }^{6}$ The constructive knowledge arose from the fact that the problem was widely reported in literature and guidance readily available to all those with responsibility for managing large property portfolios. Particular emphasis was placed on joint guidance issues by the Royal Institute of Chartered Surveyors (RICS) and the Property Care Association: see RICS, Japanese Knotweed and Residential Property (IP 27/2012).
} 
At this point it should be noted that, coincidently, in contemporaneous proceedings, the Truro County Court had reached a similar conclusion in another Japanese Knotweed case, Smith v Line. ${ }^{7}$ This concerned an application for injunctive relief against the defendant in respect of the spread of the weed from her property onto the claimant's land. In this case, the defendant had sold a parcel of land to the claimant but had retained an adjoining strip. The weed had been present on both parcels of land at the time of the sale, but the claimants had subsequently eradicated it. The defendant had failed to follow suit, and, in time, the weed spread back onto the claimant's land from the adjoining strip maintained by the defendant, due to her failure to properly manage the problem. The case raised very similar issues to Williams, although it is likely that any appeal was held in abeyance pending the outcome of that case.

\section{The main issues on appeal}

\subsection{The encroachment cases}

The main ground of appeal was framed in terms of whether pure economic loss is actionable in private nuisance. There were two main strands to the reasoning applied in the County Court judgment. Firstly, the Recorder rejected an argument that the case fell with the so-called 'encroachment cases' concerning encroaching tree roots and the like. He referred to Delaware Mansions v Westminster City Council ${ }^{8}$ as authority for the proposition that, in this subset of private nuisance, physical damage is a prerequisite. His Honour Judge Carr, in the Truro County Court, reached a similar conclusion in Smith $v$ Line. However, the Recorder in Williams delved deeper into the law and asserted that the claim 'went against the grain of legal history' in that such claims derived from a medieval form of action known as 'action on the case' (usually abbreviated to case) where physical damage was a necessary ingredient. The Court of Appeal rejected this argument on the narrow ground that the historical analysis was inaccurate and there were several examples

\footnotetext{
${ }^{7}$ [2017] 11 WLUK 106.

${ }^{8}$ [2001] UKHL 55, [2002] 1 AC 321
} 
where case based nuisance actions had covered non-physical harm. On a broader level, the Court cautioned against adopting an overly historical analysis on the grounds that:

In recent times a number of decisions at the highest level have introduced greater coherence and consistency to the legal principles governing the cause of action for private nuisance. The consequence is that it is neither necessary nor profitable to focus on historic cases of nuisance and the early development of the cause of action. ${ }^{9}$

This could lead to an overly rigid and formulaic approach which could fetter the ability of the tort to respond to changing social conditions:

The difficulty with any rigid categorisation is that it may not easily accommodate possible examples of nuisance in new social conditions or may undermine a proper analysis of factual situations which have aspects of more than one category, having regard to existing case law. ${ }^{10}$

Thus, it was necessary to recognise that 'the concept of damage in this context is a highly elastic one. ${ }^{11}$ In this respect, the Court of Appeal disagreed with the assertion that encroachments falling short of causing actual physical damage to neighbouring property should be automatically excluded from the 'encroachment cases' category.

\subsection{Pure economic loss and nuisance}

The second strand of the reasoning adopted by the Recorder in the County Court was that, notwithstanding the difficulties of categorising the claim as an encroachment case, damages were available in nuisance for purely financial loss stemming from the proximity of an undesirable

\footnotetext{
${ }^{9}$ Williams (n 1) [38] (Etherton MR).

${ }^{10}$ ibid [41] (Etherton MR).

11 ibid [42] (Etherton MR).
} 
element. In this respect, the judge relied upon a number of cases where disgruntled local residents had sought to restrain the activities of 'sex shops', brothels and so forth on the grounds that they lowered the tone of the area (see Thompson-Schwab $v$ Costaki ${ }^{12}$ and Laws $v$ Florinplace $L t d$ ). ${ }^{13} \mathrm{~A}$ similar conclusion was reached by the Truro County Court in Smith although different cases were relied on, including Bridlington Relay Ltd $v$ Yorkshire Electricity Board ${ }^{14}$ concerning interference with television reception. ${ }^{15}$

In Williams, the Court of Appeal rejected the Recorder's reasoning on the grounds that it was predicated on pure economic loss being recoverable in nuisance. The Court of Appeal considered the essential nature of the tort:

The purpose of the tort of nuisance is not to protect the value of property as an investment or a financial asset. Its purpose is to protect the owner of land (or a person entitled to exclusive possession) in their use and enjoyment of the land as such as a facet of the right of ownership or right to exclusive possession. ${ }^{16}$

Thus, undesirable activities may be actionable on the grounds that they constitute a material interference with a property right. Economic loss may be a symptom of such interferences, but it is not a cause of action in its own right. In any case, the Court of Appeal doubted whether the cases relied upon supported the argument made by the defendants in that the actions concerned applications for interlocutory relief; there was no mention of the impact of the sex establishments

\footnotetext{
12 [1956] 1 WLR 335

${ }^{13}[1981] 1$ All ER 659

${ }^{14}$ [1965] Ch 436.

${ }^{15}$ Smith (n 7) [17].

${ }^{16}$ Williams (n 1) [48] (Etherton MR).
} 
on property values. ${ }^{17}$ It appears safe to assume that the Court of Appeal would also have rejected the assertion accepted by Carr HHJ in Smith 'that the diminution in value of the property amounts to an interference in their legitimate enjoyment of the land. ${ }^{18}$

In any event, the Court was strongly of the opinion that there was in fact a physical dimension to the harm in that 'the mere presence of its rhizomes... imposes an immediate burden on the owner of the land. ${ }^{19}$ The properties had been rendered more difficult and costly to develop in that any improvement or alteration work would require the removal of contaminated soil using specialist techniques. There was authority for the proposition that heavily soiled or contaminated property can be regarded as having been physically damaged notwithstanding the fact that it can be cleaned. Thus, in the Court of Appeal decision in Hunter $v$ Canary Wharf Ltd Pill $L$ gave the example of dust which has been trodden into a carpet requiring specialist cleaning. ${ }^{20}$ In Blue Circle Industries $v$ Ministry of Defence, ${ }^{21}$ concerning liability under section 7(1)(a) of the Nuclear Installations Act 1965, soil contaminated by low levels of radiation could be regarded as physically damaged in that costly specialist techniques were required to remove and dispose of the contaminated soil.

As a result, the Court of Appeal found that an action in private nuisance could be maintained on the facts, upholding the decision of the Recorder below, albeit that his reasoning in establishing liability was flawed.

\footnotetext{
17 ibid [51] (Etherton MR).

${ }^{18}$ Smith (n 7) [17].

${ }^{19}$ Williams (n 1) [55] (Etherton MR).

20 [1996] 2 WLR 348 (CA) 366F-H.

${ }^{21}$ [1999] Ch 289 (CA).
} 


\section{Analysis}

The case is important in that it sits alongside the Supreme Court decision in Coventry $v$ Lawrence $^{22}$ as part of a concerted attempt by the senior courts to render private nuisance fit for purpose in the twenty-first century. One of the most important aspects of the judgment concerns the need to adopt a flexible approach towards the definition of actionable harm in nuisance. This has implications both for tort law doctrine and for how environmental harm is framed legally. In the attempt to use the different forms of action in private nuisance as justification for a narrow conception of physical damage, the Court of Appeal saw evidence of 'medieval chain clanking' which needed to be nipped in the bud. As Lord Atkin famously put it in United Australia Ltd v Barclays Bank $L t d$, 'When these ghosts of the past stand in the path of justice clanking their mediæval chains the proper course for the judge is to pass through them undeterred. ${ }^{23}$

For the purposes of tort law, another important aspect of the decision concerns the use of the term 'pure economic loss' in nuisance. The concept of pure economic loss in nuisance is very different to the concept of pure economic loss in negligence. In negligence, pure economic loss is used to differentiate between physical harm and loss which is not anchored in physical harm. In Spartan Steel and Alloys $v$ Martin, ${ }^{24}$ Lord Denning MR settled on policy reasons for excluding pure economic loss claims from negligence, including the classic floodgates argument. ${ }^{25}$ An arbitrary cut off point was selected beyond which financial losses were not regarded as sufficiently consequential upon the initial physical harm. In private nuisance, losses may manifest themselves in financial form, such as the diminution in the market value of a property, but this is not to say that they constitute 'pure

\footnotetext{
22 [2014] UKSC 13, [2014] AC 822.

23 [1941] AC 1 (HL) 29.

24 [1973] QB 27 (CA).

25 ibid, 38G-39A. But note that Edmund-Davies LJ (dissenting) was regarded such arbitrary policy-based cut-off points as potentially unfair and preferred a more flexible approach based upon reasonable foreseeability. See 45A (Edmund-Davies LJ).
} 
economic loss'. The infringement of a property right which sounds in nuisance 'is as concrete a form of loss as a broken arm or a smashed car ${ }^{26}$ and, as it flows immediately and directly from the infringement of the right, it would be difficult to argue that it is in some sense removed from the harm. Moreover, the policy arguments at play in negligence do not come in to play in private nuisance as the floodgates are kept shut by the need to show a sufficient interest in the affected property. Thus, as the Court of Appeal pointed out in relation to the prior sex establishment cases, claims arose from the injurious affection of the use and enjoyment of property stemming from the knowledge that unsavoury activities were being conducted in the neighbourhood; not the diminution in the market value of properties per se. The Court of Appeal was clear that 'the purpose of the tort of nuisance is not to protect the value of property as an investment or financial asset..27

This latter point raises an ambiguity since the Court of Appeal did not explain what is meant by simply using land as an investment or financial asset. Does this mean that no action would lie if the Japanese Knotweed encroached upon an area of waste ground acquired by a property speculator intent on holding onto it until the value increases - as part of a 'land bank' for example? A distinction between active use of a property and simply sitting on it in the hope that it may go up in value is not entirely unproblematic; however, there can be a fine line between simply relying on the intrinsic value of the land to generate a profit by operation of market forces and using the land for a specific business activity. The latter is clearly actionable in nuisance in that it is an aspect of the use and enjoyment of property. Suppose that the speculator in the aforementioned example decided that they wanted to develop the land but found that the Japanese Knotweed problem increased their costs; one could argue that a claim would lie in such circumstances.

\footnotetext{
${ }^{26}$ Mark Wilde, 'Magnohard Ltd v United Kingdom Atomic Energy Authority: Claiming for the Economic and Psychological “Legacy” of Nuclear and Maritime Pollution' (2004) 12Env Liability 243, 244.

${ }^{27}$ Williams (n 1) [48].
} 
In thinking about how the reasoning in Williams conceptualises environmental harm in common law reasoning, the Court made the point that the harm in question could be construed as physical in any case. This was important for the doctrine of private nuisance to be applicable. In the past, a narrow conception of damage and a readiness to dismiss it as pure economic loss has served to restrict the use of tort in an environmental context. By using the language of 'contamination' to describe the presence of Japanese Knotweed, the Court was able to characterise the issue as one of environmental harm requiring specialist decontamination measures. This characterisation may have broader implications.

A potential example of such implications is in relation to nuclear contamination. In Merlin $v$ British Nuclear Fuels $L t d{ }^{28}$ the High Court had to determine whether radioactive dust constituted actionable harm within the meaning of section 7 of the Nuclear Installations Act 1965. In the absence of any definitions of harm in the statute, Gatehouse J fell back upon the common law where he noted that pure economic loss was not generally recoverable. It is clear that he was primarily concerned with negligence and did not engage with the finer points about what constitutes pure economic loss in nuisance. This led him to the conclusion that the presence of contaminated dust could not be regarded as physical damage. Tromans noted that this approach was problematic:

[T] he distinction seems to leave the law in a difficult state. How is removal of dust which is dissipated throughout a house substantially different to the removal of a layer of contaminated topsoil? If anything, it might be more difficult to remove dust which was in the interstices of roof spaces, floorboards, etc. ${ }^{29}$

\footnotetext{
${ }^{28}$ [1990] 3 WLR 383.

${ }^{29}$ Stephen Tromans, 'Nuclear Liabilities and Environmental Damage' (1999) 1 Env Law Rev 59, 61.
} 
Should the facts of Merlin be repeated, it seems that a different outcome may be reached. The Williams decision provides clear authority for the proposition that contaminated dust constitutes physical damage in that it is something which has to be cleaned up using specialist techniques. However, one could also argue that the mere presence of dust would give rise to a cause of action; not because it causes a financial detriment but because it interferes with the use and enjoyment of the property. The financial detriment should be regarded as inextricably intertwined with the violation of a property right and should not, therefore, be dismissed as pure economic loss and thus excluded from the scope of the statutory regime. Clearly, such harms have an environmental dimension and the ability to frame them as concrete losses which cannot be dismissed as pure economic losses can only serve to extend the potential reach of tort in this context.

\section{Conclusion}

Overall the decision offers important clarifications of the nature of harm in nuisance which may widen the scope of the tort. For one thing, it seeks to undo much confusion caused by the importation of pure economic loss concepts from negligence into private nuisance. In nuisance, the loss is usually securely anchored in the infringement of the property right and cannot be regarded as 'pure' economic loss. Moreover, the decision pushes back against the forms of action trying to reassert themselves along the lines of physical and non-physical harm in the so-called encroachment cases. In this respect, the decision may serve to lessen the need to prove physical damage and strengthen the role of the amenity breed of nuisance. In a secondary argument, the Court of Appeal considered that the harm could be regarded as physical in any event. This aspect of the judgment may have more far-reaching implications in terms of how environmental harm is conceptualized for the purposes of the common law. 